\title{
WATER AND SALT STRESSES ON GERMINATION OF COWPEA (Vigna unguiculata cv. BRS Tumucumaque) SEEDS ${ }^{1}$
}

 \\ ROCHA $^{2}$, MARCO ANTONIO CAMILLO DE CARVALHO ${ }^{2}$, OSCAR MITSUO YAMASHITA ${ }^{2}$
}

\begin{abstract}
The objective of this work was to evaluate seeds of cowpea, cultivar BRS Tumucumaque, subjected to different water stresses induced by polyethylene glycol (PEG-6000) and mannitol and different salt stresses induced by $\mathrm{NaCl}$ and $\mathrm{CaCl}_{2}$ solutions. The water and salt stresses was evaluated in laboratory using completely randomized experimental designs in $2 \times 6$ factorial arrangements, with six osmotic potentials $(0.0$, $-0.2,-0.4,-0.6,-0.8$ and $-1.0 \mathrm{MPa}$ ) and two stress inducers for each experiment, with four replications of 50 seeds. The percentage of germination, germination speed index, root and shoot lengths and seedling fresh weight were evaluated at the tenth day (end of the evaluation period). The simulated water stress showed effects on the cowpea seed germination and seedling initial growth by decreasing the rates of the variables evaluated, which had greater effect in treatments with PEG-6000. The salt stress induced by $\mathrm{NaCl}$ showed greater effect on the variables evaluated than that induced by $\mathrm{CaCl}_{2}$, due to the sodium toxicity in the salt chemical composition.
\end{abstract}

Keywords: Germination speed index. Water deficit. Osmotic potential.

\section{ESTRESSE HÍDRICO E SALINO NA GERMINAÇÃO DE SEMENTES DE FEIJÃO-CAUPI (Vigna unguiculata cv. BRS Tumucumaque)}

\begin{abstract}
RESUMO - O objetivo deste trabalho foi avaliar o comportamento de sementes das sementes da cultivar de feijão-caupi BRS Tumucumaque sob efeito de potenciais hídricos provocados por polietileno glicol (PEG 6000 ) e manitol e de potenciais salinos induzidos por soluções de $\mathrm{NaCl}$ e $\mathrm{CaCl}_{2}$. Para verificação dos estresses hídrico e salino, avaliou-se em laboratório, a combinação de seis potenciais osmóticos $(0,0 ;-0,2 ;-0,4 ;-0,6 ;-0,8$ e $-1,0 \mathrm{MPa}$ ) com os dois agentes de estresses para cada experimento, em delineamento inteiramente casualizado, configurando esquema fatorial $2 \times 6$, com quatro repetições de 50 sementes. Foram avaliadas as variáveis: porcentagem de germinação, índice de velocidade de germinação (IVG), comprimento de raiz e parte aérea e massa fresca de plântulas no décimo dia, ao final do período de avaliação. A simulação de deficiência hídrica, utilizando-se manitol e PEG 6000 permitiu a constatação dos efeitos do estresse na germinação e no crescimento inicial das plântulas da cultivar BRS Tumucumaque, pelo decréscimo das variáveis observadas, sendo que os tratamentos à base de PEG 6000 foram os mais drásticos. A indução do estresse salino pelos sais $\mathrm{NaCl}$ e $\mathrm{CaCl}_{2}$ foi verificada nas variáveis avaliadas, onde os efeitos do $\mathrm{NaCl}$ foram mais acentuados, devido a toxidade do sódio na composição química do sal.
\end{abstract}

Palavras-chave: Índice de velocidade de germinação. Restrição hídrica. Potencial osmótico.

\footnotetext{
${ }^{*}$ Corresponding author

${ }^{1}$ Received for publication in $08 / 12 / 2016$; accepted in $03 / 02 / 2017$

Paper approved from IV CONAC 2016.

${ }^{2}$ Graduate Program in Biodiversity and Amazon Agroecosystens, Universidade do Estado de Mato Grosso, Alta Floresta, MT, Brazil; aurianeferreira@hotmail.com, ricardofelito@hotmail.com, admr.maltezo@hotmail.com,marcocarvalho@unemat.br, yama@unemat.br.
} 


\section{INTRODUCTION}

Cowpea (Vigna unguiculata (L.) Walp.) is one of the most adaptable, versatile and nutritious legume crop species. This species is an important food and an essential component of production in dry-climate regions of the tropics, and parts of Asia, United States of America, Middle East and Central and South Americas (BEZERRA et al., 2014). In Brazil, cowpea is cultivated mainly in the semiarid region (Northeast), since it is adapted to the soil and climate conditions of this region (DAMASCENO-SILVA, 2009). This legume, is an important source of protein, energy, fiber and minerals for human and animal nutrition, and generate employment and income for the producing regions. Thus, cowpea is considered one of the main subsistence crops of the Brazilian semiarid Sertão region (EMBRAPA, 2002).

Cowpea is one of the most consumed legumes in the Northeast of Brazil, however, this region has the lowest cowpea crop yields of the country. The State of Rio Grande do Norte, for example, had average yield of $555 \mathrm{~kg} \mathrm{ha}^{-1}$ in 2013/2014, and estimate yield of $353 \mathrm{~kg} \mathrm{ha}^{-1}$ for the 2014/2015 crop season (CONAB, 2015). This low yield is due to several factors, such as low technology and water deficit, especially in critical times for crop development.

The relatively short crop cycle of cowpea $(60$ to 80 days) and its good development under low fertility soils (EMBRAPA, 2002) are factors that enable grain yields around $1,000 \mathrm{~kg} \mathrm{ha}^{-1}$ in the Center-West region of Brazil (FILGUEIRAS et al., 2009), in which cowpea have expanded to large scale crops, especially after soybean crop seasons, as second crops or off-season crops (CASTELLETTI; COSTA, 2013).

Cowpea has been intensively researched, especially for genetic improvement, crop management and biological nitrogen fixation capacity (SILVA JÚNIOR et al., 2014). However, some aspects of this species still require scientific studies to be better understood. One of these aspects is seed germination capacity of cowpea, whose development, apparently, is not so affected by stresses, such as reduced amounts of water. Germination is a critical stage for any plant and can be negatively affected by several factors, such as water deficit and excess salts in the soil solution (LARCHER, 2006). However, little information on the response of cowpea to these conditions is found.

Different compounds have been used to simulate water deficit conditions in substrates for seed germination tests of many species, such as PEG-6000 (polyethylene glycol-6000) and mannitol, which are inert non-toxic compounds. A frequently used method to determine the plant tolerance to salt stress is the evaluation of seed germination capacity in substrates under saline conditions (TAIZ;
ZEIGER, 2013); and the most used salts are $\mathrm{NaCl}$ and $\mathrm{CaCl}_{2}$.

Plants of sensitive species to environments with high salt concentrations in the substrate during the initial processes of germination may have limited development and chances of survival (DI TOMMASO, 2004).

Information on the effect of stress on seed germination is important for ecophysiology, assisting in assessing the tolerance limits and adaptive capacity of species (LARCHER, 2006).

The objective of this work was to evaluate seeds of cowpea, cultivar BRS Tumucumaque, subjected to different water stresses induced by polyethylene glycol (PEG-6000) and mannitol and different salt stresses induced by $\mathrm{NaCl}$ and $\mathrm{CaCl}_{2}$ solutions.

\section{MATERIAL AND METHODS}

The experiments were conducted in the Laboratory of Seed Technology and Weed Control (LaSeM) of the Mato Grosso State University, campus Alta Floresta. Seeds of the cultivar BRS Tumucumaque were used.

Seeds were subjected to different simulated water stresses to determine their maximum tolerance to drought. A completely randomized design in a $2 \times 6$ factorial arrangement was used, with six osmotic potentials $(0.0,-0.2,-0.4,-0.6,-0.8$ and $-1.0 \mathrm{MPa})$ induced by solutions of mannitol and polyethylene glycol (PEG-6000), with four replications of 50 seeds. The solutions were prepared by dissolving PEG-6000 (VILLELA; DONI FILHO; SIQUEIRA, 1991) and mannitol (calculated by the Van't Hoff equation as described by (BRAGA et al., 1999)) in deionized water to each osmotic potential used.

Seed were subjected to different salt stresses to determine their maximum tolerance to salts. A completely randomized design in a $2 \times 6$ factorial arrangement was used, with six osmotic potentials $(0.0,-0.2,-0.4,-0.6 ;-0.8$ and $-1.0 \mathrm{MPa})$ induced by sodium chloride $(\mathrm{NaCl})$ and calcium chloride $\left(\mathrm{CaCl}_{2}\right)$ solutions, with four replications of 50 seeds. The saline solutions were prepared according to the Van't Hoff equation described by Braga et al. (1999).

Experimental units consisted of acrylic germination boxes $(11.0 \times 11.0 \times 3.5 \mathrm{~cm})$ previously subjected to aseptic cleaning with sodium hypochlorite $(10 \%)$ two hours before the experiment implementations. The seeds were placed to germinate in these boxes on two sheets of germination-test paper (previously autoclaved) and moistened with solutions at proportions of 2.5 -fold the weight of the dry substrate (BRASIL, 2009), and then taken to BOD germination chambers, set to a light period of $12 \mathrm{~h} \mathrm{day}^{-1}$ (four white lamps) and constant temperature of $25^{\circ} \mathrm{C}$. 
Percentage of germination, germination speed index, root and shoot lengths, and fresh seedling weight were evaluated at the tenth day (end of the evaluation period).

Germination was evaluated considering as germinated the seeds that developed primary root with a length equal to or greater than $2 \mathrm{~mm}$. The number of germinated seeds was counted daily over ten days (BRASIL, 2009).

Germination speed index (GSI) was determined together with the germination test, using the equation proposed by Maguire (1962):

$$
G S I=\frac{N_{1}}{D_{1}}+\frac{N_{2}}{D_{2}}+\ldots+\frac{N_{n}}{D_{n}}
$$

wherein $\mathrm{N}_{\mathrm{i}}$ is the number of seedlings germinated on day $1,2, \ldots, n$; and $D_{i}$ are the number of days for germination.

Shoot and root lengths of seedlings were determined at the end of the evaluation period, using all the normal seedlings of each treatment, by measurements with a graduated ruler $(\mathrm{mm})$. The mean shoot and root lengths of the seedlings of each sample were calculated by dividing the sum of the lengths by the number of seedlings evaluated.

Fresh seedling weight represented the mean seedling weight $(\mathrm{g})$ of each treatment, measured by weighing the seedlings in a 0.001-g precision balance.

All results were subjected to analysis of variance. Means of the qualitative factors were compared by the Tukey's test at $5 \%$ of probability and means of quantitative factor (osmotic potentials) to polynomial regression, using the statistical program Sisvar (FERREIRA, 2011).

\section{RESULTS AND DISCUSSION}

Seed germination capacity and seedling initial development of cowpea were different $(p<0.05)$ between the treatments with PEG-6000 and mannitol, with interaction between the solutions used and osmotic potentials for all characteristics. The effect of PEG-6000 on germination and germination speed index (GSI) was more pronounced than that of mannitol in all osmotic potentials with solutions (Table 1).

Table 1. Percentage of germination and germination speed index of cowpea seeds, cultivar BRS Tumucumaque, subjected to different water stresses induced by PEG-6000 and Mannitol.

\begin{tabular}{|c|c|c|c|c|c|c|}
\hline \multirow[b]{2}{*}{ Product } & \multicolumn{6}{|c|}{ Concentration $(\mathrm{MPa})$} \\
\hline & 0 & -0.2 & -0.4 & -0.6 & -0.8 & -1.0 \\
\hline & \multicolumn{6}{|c|}{$\%$ Germination } \\
\hline Mannitol & $97.25 \mathrm{a}$ & $93.25 \mathrm{a}$ & $92.00 \mathrm{a}$ & $92.00 \mathrm{a}$ & $92.00 \mathrm{a}$ & $86.00 \mathrm{a}$ \\
\hline PEG-6000 & $94.00 \mathrm{a}$ & $28.00 \mathrm{~b}$ & $1.00 \mathrm{~b}$ & $0.00 \mathrm{~b}$ & $0.00 \mathrm{~b}$ & $0.00 \mathrm{~b}$ \\
\hline \multirow[t]{2}{*}{$\mathrm{CV} \%$} & \multicolumn{6}{|c|}{6.05} \\
\hline & \multicolumn{6}{|c|}{ Germination speed index } \\
\hline Mannitol & $13.64 \mathrm{a}$ & $8.50 \mathrm{a}$ & $10.40 \mathrm{a}$ & $9.18 \mathrm{a}$ & $9.75 \mathrm{a}$ & $6.65 \mathrm{a}$ \\
\hline PEG-6000 & $13.53 \mathrm{a}$ & $1.44 \mathrm{~b}$ & $0.05 \mathrm{~b}$ & $0.00 \mathrm{~b}$ & $0.00 \mathrm{~b}$ & $0.00 \mathrm{~b}$ \\
\hline $\mathrm{CV} \%$ & \multicolumn{6}{|c|}{12.29} \\
\hline
\end{tabular}

Means followed by the same letter in the columns did not differ statistically by the Tukey's test $(\mathrm{p}<0.05)$.

Considering the decrease in germination from the condition without water deficit to the first osmotic potential evaluated $(-0.2 \mathrm{MPa})$, the use of PEG-6000 caused an absolute reduction of $66 \%$ $(70 \%$ in relative terms) in germination, while mannitol reduced the germination in only $4 \%$. No germination occurred with the use of PEG-6000 from -0.6 MPa.

Similar results were found for other species. Moraes, Menezes and Pasqualli (2005) evaluated osmotic potentials on common bean (Phaseolus vulgaris L.) seeds and found reduced germination $(\mathrm{p}<0.05)$ from $-0.2 \mathrm{MPa}$, with no normal seedling formation from -0.25 MPa. Souza et al. (2008) evaluated water stress induced by PEG-6000 in Plantago ovata seeds and found reduced germination and GSI from $-0.2 \mathrm{MPa}$, which were totally inhibited at osmotic potentials of -0.6 and $-0.8 \mathrm{MPa}$. The use of mannitol showed a linear decrease in germination and GSI as a function of the osmotic potentials evaluated (Figure 1). On the other hand, the use of PEG-6000 showed no germination from $-0.47 \mathrm{MPa}$ and the GSI from $-0.42 \mathrm{MPa}$.

Solutions with PEG have high viscosity, compromise absorption of $\mathrm{O}_{2}$, cause greater water deficit and prevent absorption of water by seeds (YOON et al., 1997). These effects are not observed with mannitol, which is a neutral substance of very low viscosity.

Similar to the results for germination and GSI, PEG-6000 caused greater stress than mannitol, hindering root development, shoot length and fresh seedling weight (Table 2). Pelegrini et al. (2013) evaluated Erythrina falcate and also found $-0.2 \mathrm{MPa}$ as the maximum tolerance limit for vegetative development using PEG-6000, causing greater effect than mannitol. 



Figure 1. Percentage of germination (A) and germination speed index (GSI) (B) of cowpea seeds, cultivar BRS Tumucumaque, subjected to different water stresses induced by PEG-6000 and mannitol.

Table 2. Root and shoot lengths and fresh weight of cowpea seedlings, cultivar BRS Tumucumaque, subjected to different water stresses induced by PEG-6000 and mannitol.

\begin{tabular}{|c|c|c|c|c|c|c|}
\hline \multirow[b]{2}{*}{ Product } & \multicolumn{6}{|c|}{ Concentration $(\mathrm{MPa})$} \\
\hline & 0 & -0.2 & -0.4 & -0.6 & -0.8 & -1.0 \\
\hline & \multicolumn{6}{|c|}{ Root length } \\
\hline Mannitol & $43.80 \mathrm{a}$ & $19.17 \mathrm{a}$ & $15.31 \mathrm{a}$ & $15.92 \mathrm{a}$ & $13.86 \mathrm{a}$ & $12.08 \mathrm{a}$ \\
\hline PEG-6000 & $41.27 \mathrm{a}$ & $12.28 \mathrm{~b}$ & $0.00 \mathrm{~b}$ & $0.00 \mathrm{~b}$ & $0.00 \mathrm{~b}$ & $0.00 \mathrm{~b}$ \\
\hline \multirow[t]{2}{*}{$\mathrm{CV} \%$} & \multicolumn{6}{|c|}{25.46} \\
\hline & \multicolumn{6}{|c|}{ Shoot length } \\
\hline Mannitol & $37.96 \mathrm{a}$ & $6.85 \mathrm{a}$ & $10.33 \mathrm{a}$ & $8.69 \mathrm{a}$ & $8.11 \mathrm{a}$ & $7.41 \mathrm{a}$ \\
\hline PEG-6000 & $36.23 \mathrm{a}$ & $0.00 \mathrm{~b}$ & $0.00 \mathrm{~b}$ & $0.00 \mathrm{~b}$ & $0.00 \mathrm{~b}$ & $0.00 \mathrm{~b}$ \\
\hline \multirow[t]{2}{*}{$\mathrm{CV} \%$} & \multicolumn{6}{|c|}{24.63} \\
\hline & \multicolumn{6}{|c|}{ Fresh weight } \\
\hline Mannitol & $0.57 \mathrm{a}$ & $0.41 \mathrm{a}$ & $0.41 \mathrm{a}$ & $0.40 \mathrm{a}$ & $0.38 \mathrm{a}$ & $0.38 \mathrm{a}$ \\
\hline PEG-6000 & $0.57 \mathrm{a}$ & $0.00 \mathrm{~b}$ & $0.00 \mathrm{~b}$ & $0.00 \mathrm{~b}$ & $0.00 \mathrm{~b}$ & $0.00 \mathrm{~b}$ \\
\hline $\mathrm{CV} \%$ & \multicolumn{6}{|c|}{8.49} \\
\hline
\end{tabular}

Means followed by the same letter in the columns did not differ statistically by the Tukey's test $(\mathrm{p}<0.05)$.

The effects of mannitol on root and shoot lengths were similar (Figure 2), with water deficits from $-0.2 \mathrm{MPa}$ hindering these characteristics. On the other hand, PEG-6000 caused a more pronounced effect, with no root development from $-0.47 \mathrm{MPa}$, and no shoot development from -0.2 $\mathrm{MPa}$. Although PEG-6000 is not a toxic or electrolytic product, its high molecular weight prevents its penetration into the cells (PEREZ; FANTI; CASALI, 2001), since it makes the solution denser, hindering the absorption of water by seeds. However, according to Heydecker and Coolbear (1977), PEG can also reduce oxygen availability, contributing to reduce germination and initial seedling development.

Mannitol is an alcoholic sugar that can be used as an osmotic stabilizer in plant tissue cultures and is not easily absorbed (MACHADO NETO et al., 2006). This characteristic may explain the higher results for germination and seedling development in all osmotic potentials with mannitol.

The inducers of salt stress showed interaction with the osmotic potentials evaluated for germination and GSI (Table 3). Differences between salts occurred only in the most negative osmotic potential $(-1.0 \mathrm{MPa})$, with $\mathrm{NaCl}$ showing greater effect on germination and GSI. The decrease in germination was not very pronounced at lower concentrations of salts, showing an absolute reduction of $5.25 \%$ up to $-0.8 \mathrm{MPa}$ for $\mathrm{NaCl}$. Seeds at the highest concentration of $\mathrm{NaCl}$ showed no germination. $\mathrm{CaCl}_{2}$ had little effect on germination. Comparing the most negative $(-1.0 \mathrm{MPa})$ with the highest $(0.0 \mathrm{MPa})$ osmotic potential induced by $\mathrm{CaCl}_{2}$, the germination reduced $29 \%$ and GSI reduced $73 \%$, thus, $\mathrm{CaCl}_{2}$ had a more pronounced action on the speed of germination.

Excess salts causes cytotoxicity, cell dehydration (TAIZ; ZEIGER, 2013) and reduces metabolic activity and synthesis of new tissues of seeds, due to reduction of water availability (MARCOS FILHO, 2015), resulting in a lower germination speed and, in more severe cases, the loss of germination capacity. 


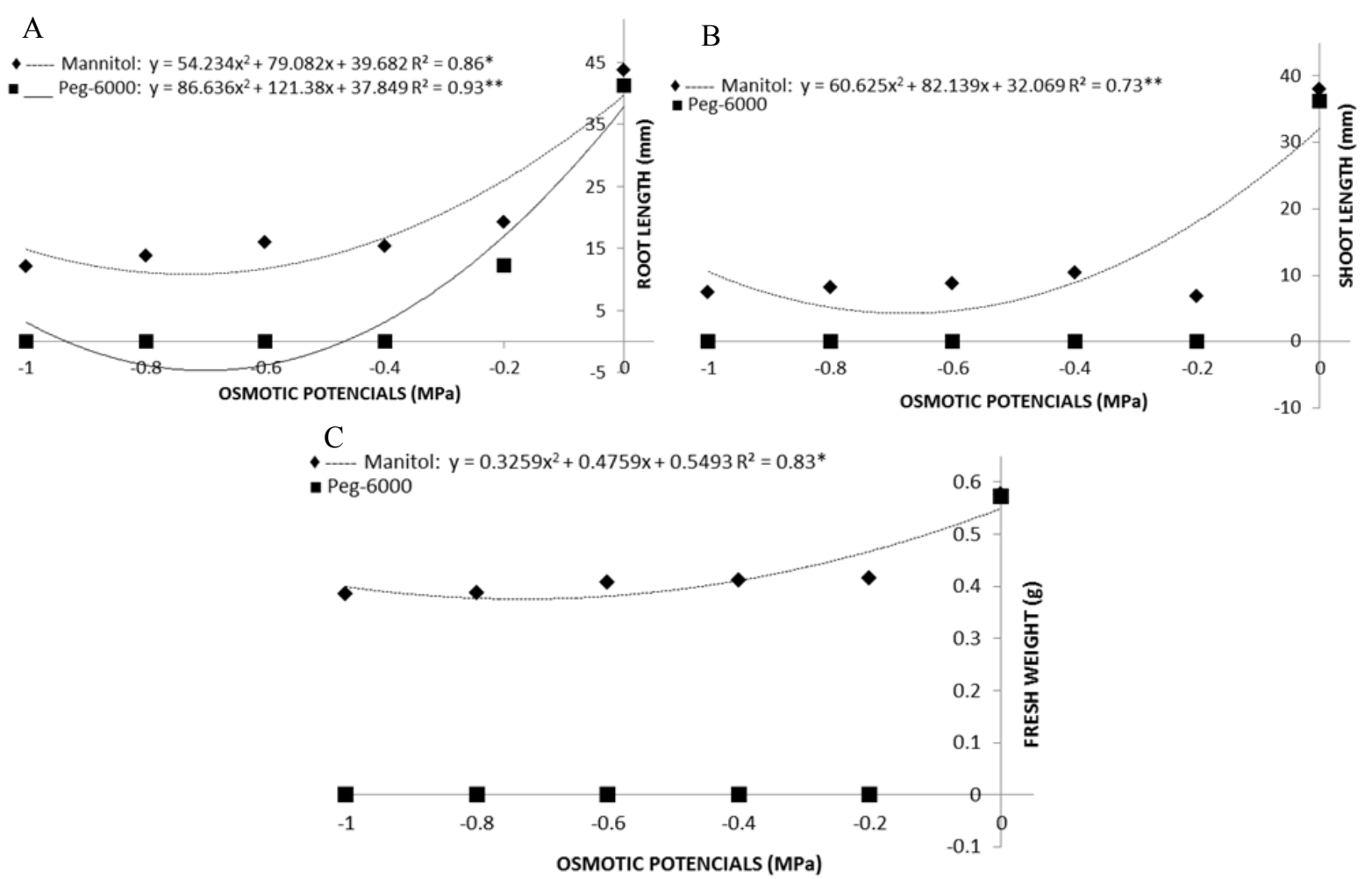

Figure 2. Root (A) and shoot (B) lengths and fresh weight (C) of cowpea seedlings, cultivar BRS Tumucumaque, subjected to different water stresses induced by PEG-6000 and mannitol.

Table 3. Percentage of germination and germination speed index (GSI) of cowpea seeds, cultivar BRS Tumucumaque, subjected to different salt stresses induced by $\mathrm{NaCl}$ and $\mathrm{CaCl}_{2}$ solutions.

\begin{tabular}{|c|c|c|c|c|c|c|}
\hline \multirow[b]{2}{*}{ Salt } & \multicolumn{6}{|c|}{ Concentration (MPa) } \\
\hline & 0.0 & -0.2 & -0.4 & -0.6 & -0.8 & -1.0 \\
\hline & \multicolumn{6}{|c|}{$\%$ germination } \\
\hline $\mathrm{NaCl}$ & $97.25 \mathrm{a}$ & $97.25 \mathrm{a}$ & $94.75 \mathrm{a}$ & $93.25 \mathrm{a}$ & $92.00 \mathrm{a}$ & $0.00 \mathrm{~b}$ \\
\hline $\mathrm{CaCl}_{2}$ & $97.25 \mathrm{a}$ & $96.00 \mathrm{a}$ & $94.75 \mathrm{a}$ & $92.00 \mathrm{a}$ & $89.25 \mathrm{a}$ & $69.00 \mathrm{a}$ \\
\hline \multirow[t]{2}{*}{$\mathrm{CV} \%$} & \multicolumn{6}{|c|}{5.44} \\
\hline & \multicolumn{6}{|c|}{ GSI } \\
\hline $\mathrm{NaCl}$ & $16.41 \mathrm{a}$ & $13.43 \mathrm{a}$ & $11.28 \mathrm{a}$ & $8.58 \mathrm{a}$ & $7.86 \mathrm{a}$ & $0.00 \mathrm{~b}$ \\
\hline $\mathrm{CaCl}_{2}$ & $16.41 \mathrm{a}$ & $12.53 \mathrm{a}$ & $10.96 \mathrm{a}$ & $9.66 \mathrm{a}$ & $9.43 \mathrm{a}$ & $4.33 \mathrm{a}$ \\
\hline CV\% & \multicolumn{6}{|c|}{14.37} \\
\hline
\end{tabular}

Means followed by the same letter in the columns did not differ statistically by the Tukey's test $(\mathrm{p}<0.05)$.

Seeds maintained under salt stress induced by $\mathrm{NaCl}$ and $\mathrm{CaCl}_{2}$ had similar germination up to the osmotic potential of $-0.8 \mathrm{MPa}$, with germination and GSI gradually decreasing with decreasing osmotic potentials. $\mathrm{NaCl}$ totally inhibited the germination at osmotic potential of $-1.0 \mathrm{MPa}$, indicating that, when induced by this salt, the osmotic potential of $-0.8 \mathrm{MPa}$ is the limit for cowpea germination.

Germination showed a quadratic trend as response to increasing osmotic potentials induced by $\mathrm{CaCl}_{2}$ and $\mathrm{NaCl}$, with maximum germination at $-0.2 \mathrm{MPa}$, and no germination at $-1.0 \mathrm{MPa}$ (Figure 3). Similar results were found by Coelho et al. (2010), in common beans, with osmotic potential of $-0.25 \mathrm{MPa}$ induced by $\mathrm{NaCl}$ causing the maximum germination.
The osmotic potential of -1.0 MPa induced by $\mathrm{CaCl}_{2}$ showed germination close to $69 \%$, denoting the more pronounced effect of $\mathrm{NaCl}$ compared with $\mathrm{CaCl}_{2}$.

Machado Neto et al. (2006) also found lower effect of $\mathrm{CaCl}_{2}$ on germination of common beans compared with $\mathrm{NaCl}$ solutions. Presence of sodium ions may destabilize the osmotic potential and membrane equilibrium of plants, directing their metabolism to repair cellular structures, causing a reduced development. On the other hand, calcium acts as a membrane stabilizer and cell signal for various forms of stress, activating the catalase for example, an enzyme involved in the maintenance of cell integrity (YANG; POOVAIAH, 2002). 


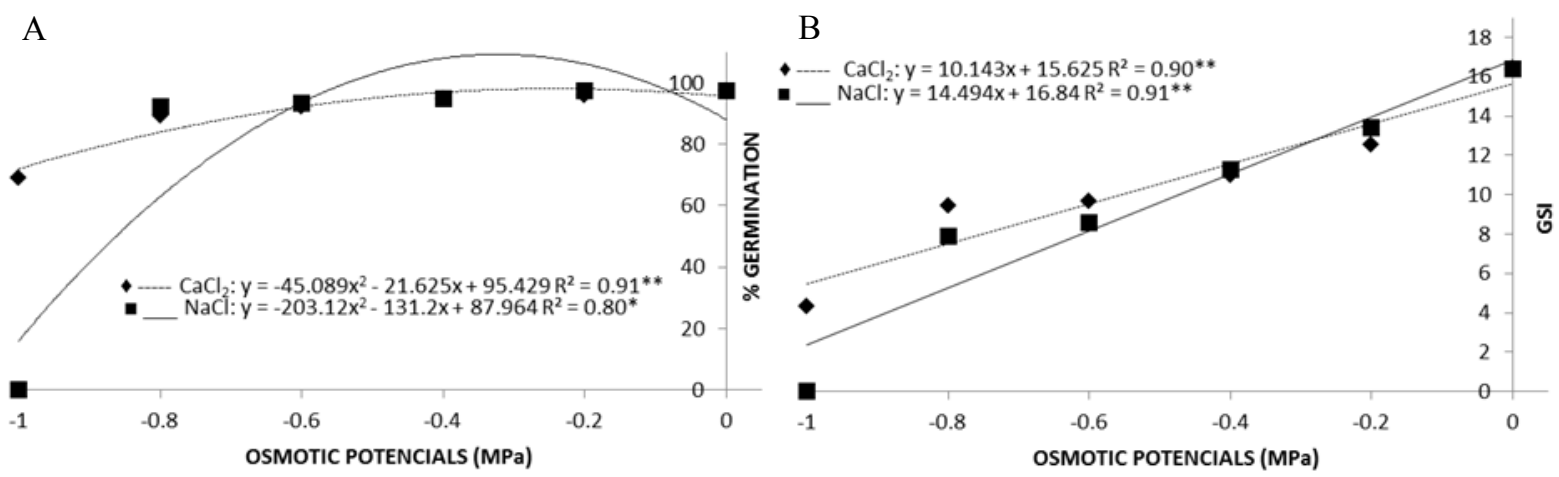

Figure 3. Percentage of germination (A) and germination speed index (GSI) (B) of cowpea seeds, cultivar BRS Tumucumaque, subjected to different salt stresses induced by $\mathrm{NaCl}$ and $\mathrm{CaCl}_{2}$ solutions.

The salts used and osmotic potentials evaluated showed no interaction for the variables root length and shoot length, showing only isolated effects on them.

The $\mathrm{NaCl}$ caused a greater deleterious effect on seedling root and shoot lengths, with poor formation of these structures, showing lower mean lengths than those of seedlings subjected to $\mathrm{CaCl}_{2}$ solutions (Table 4). The $\mathrm{Ca}^{2+}$ ion is essential in maintaining the plasma membrane integrity, and is responsible for activating a series of enzymes involved in plant growth (FRANCO et al., 1999). These characteristics may explain the lower stress caused by $\mathrm{CaCl}_{2}$.

Table 4. Root and shoot lengths of cowpea seedlings, cultivar BRS Tumucumaque, subjected to different salt stresses induced by $\mathrm{NaCl}$ and $\mathrm{CaCl}_{2}$ solutions.

\begin{tabular}{lll}
\hline \multirow{2}{*}{ Salt } & \multicolumn{3}{c}{ Length $(\mathrm{mm})$} \\
\cline { 2 - 3 } & Root & Shoot \\
\hline $\mathrm{NaCl}$ & $23.62 \mathrm{~b}$ & $16.76 \mathrm{~b}$ \\
$\mathrm{CaCl}$ & $31.26 \mathrm{a}$ & $21.57 \mathrm{a}$ \\
\hline $\mathrm{CV} \%$ & 21.80 & 24.99 \\
\hline
\end{tabular}

Means followed by the same letter in the columns did not differ statistically by the Tukey's test $(\mathrm{p}<0.05)$.

The cowpea root and shoot lengths showed decreasing linear responses to increasing water stress induced by salts (Figure 4). The increasing osmotic potential induced by $\mathrm{CaCl}_{2}$ and $\mathrm{NaCl}$ negatively affected the root growth. The decreased water potential and increased salinization caused less tissue elongation, since tissue elongation and carbohydrate synthesis are processes dependent on water stress (WENKERT; LEMON; SINCLAIR, 1978). Based on the mathematical models, root length was more affected than shoot length, with mean reductions of $38.1 \mathrm{~mm}$ (root) and $32.3 \mathrm{~mm}$ (shoot) from the osmotic potentials of 0 to $-1 \mathrm{MPa}$.

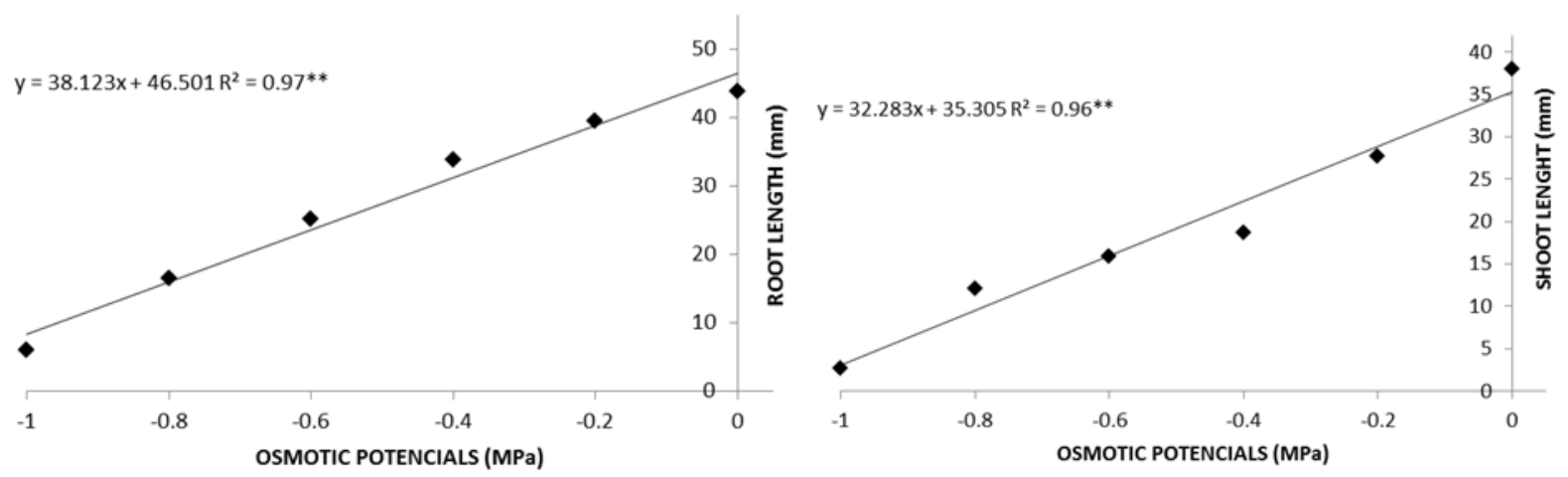

Figure 4. Root (A) and shoot (B) lengths of cowpea seedlings, cultivar BRS Tumucumaque, subjected to different salt stresses induced by $\mathrm{NaCl}$ and $\mathrm{CaCl}_{2}$ solutions. 
The salts used and osmotic potentials evaluated showed a significant interaction for fresh seedling weight. The salts showed different effects on fresh seedling weight only in the lower osmotic potential, with $\mathrm{NaCl}$ causing a more pronounced effect compared with $\mathrm{CaCl}_{2}$ (Table 5).

Fresh seedling weight showed linear response to increasing osmotic potentials induced by $\mathrm{CaCl}_{2}$, and a quadratic response to increasing osmotic potentials induced by $\mathrm{NaCl}$ (Figure 5). Calcium chloride was efficient as osmotic agent in showing the cowpea responses to water stress, however, its effect was not very pronounced as that of the $\mathrm{NaCl}$ at osmotic potentials of up to $-1.0 \mathrm{MPa}$.

Table 5. Fresh weight of cowpea seedlings, cultivar BRS Tumucumaque, subjected to different salt stresses induced by $\mathrm{NaCl}$ and $\mathrm{CaCl}_{2}$ solutions.

\begin{tabular}{|c|c|c|c|c|c|c|}
\hline \multirow{2}{*}{ Salt } & \multicolumn{6}{|c|}{ Osmotic potentials (MPa) } \\
\hline & 0.0 & -0.2 & -0.4 & -0.6 & -0.8 & -1.0 \\
\hline & \multicolumn{6}{|c|}{ Fresh weight } \\
\hline $\mathrm{NaCl}$ & $0.57 \mathrm{a}$ & $0.54 \mathrm{a}$ & $0.43 \mathrm{a}$ & $0.41 \mathrm{~b}$ & $0.41 \mathrm{a}$ & $0.00 \mathrm{~b}$ \\
\hline $\mathrm{CaCl}_{2}$ & $0.57 \mathrm{a}$ & $0.50 \mathrm{a}$ & $0.46 \mathrm{a}$ & $0.47 \mathrm{a}$ & $0.46 \mathrm{a}$ & $0.36 \mathrm{a}$ \\
\hline $\mathrm{CV} \%$ & \multicolumn{6}{|c|}{8.57} \\
\hline
\end{tabular}

Means followed by the same letter in the columns did not differ statistically by the Tukey's test $(\mathrm{p}<0.05)$.

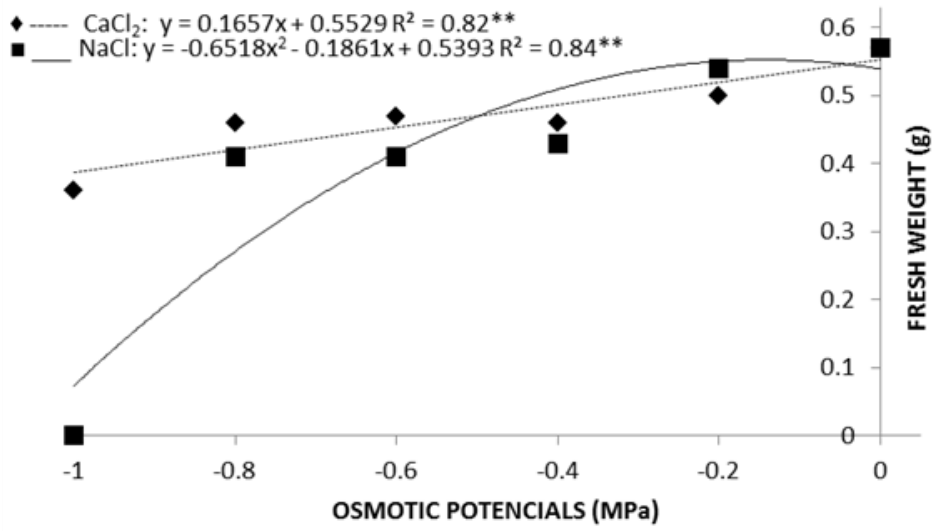

Figure 5. Fresh weight of cowpea seedlings, cultivar BRS Tumucumaque, subjected to different salt stresses induced by $\mathrm{NaCl}$ and $\mathrm{CaCl}_{2}$ solutions.

\section{CONCLUSIONS}

Seed germination and initial seedling development of cowpea, cultivar BRS Tumucumaque, are negatively affected by water stress induced by PEG-6000 (from $-0.2 \mathrm{MPa}$ ) and mannitol (from $-0.8 \mathrm{MPa}$ ), with more pronounced effect when induced by PEG-6000.

Salt stress induced by $\mathrm{NaCl}$ and $\mathrm{CaCl}_{2}$ is detrimental to germination, germination speed index and initial seedling development of cowpea, cultivar BRS Tumucumaque, with the highest effect occurring from $-0.80 \mathrm{MPa}$ for both salts.

Salt stress induced by $\mathrm{NaCl}$ has greater effect on germination and initial seedling development of cowpea, cultivar BRS Tumucumaque, than that induced by $\mathrm{CaCl}_{2}$.

\section{REFERENCES}

BEZERRA, M. A. F. et al. Cultivo de feijão-caupi em Latossolos sob o efeito residual da adubação fosfatada. Revista Caatinga, Mossoró, v. 27, n. 1, p.
109-115, 2014.

BRAGA, L. F. et al. Efeito da disponibilidade hídrica do substrato na qualidade fisiológica de sementes de feijão. Revista Brasileira de Sementes, Viçosa, v. 21, n. 2, p. 95-102, 1999.

BRASIL. Ministério da Agricultura e Reforma Agrária. Regras para Análise de Sementes. Brasília: SAND/DNDV/CLAV, 2009. 365 p.

CASTElletTI, C. H. M.; COSTA, A. F. Feijãocaupi: alternativa sustentável para os sistemas produtivos. Pesquisa Agropecuária Pernambucana, Brasília, v. 18, n. 1, p. 1-2, 2013.

COELHO, D. L. M. et al. Estresse hídrico com diferentes osmóticos em sementes de feijão e expressão diferencial de proteínas durante a germinação. Acta Scientiarum Agronomy, Maringá, v. 32, n. 3, p. 491-499, 2010.

COMPANHIA NACIONAL DE ABASTECIMENTO - CONAB. Acompanhamento da safra brasileira de grãos, v. 2 - Safra 2014/15, n.

Rev. Caatinga, Mossoró, v. 30, n. 4, p. 1009 - 1016, out. - dez., 2017 
10 - Décimo levantamento, Brasília, p. 1-109, julho 2015. Disponível em: <http://www.conab.gov.br/ conteudos.php?

$\mathrm{a}=1252 \& \mathrm{t}=2 \&$ Pagina_objemsconteudos $=2 \# \mathrm{~A}$

objcmsconteudos>. Acesso em: 24 jul. 2016.

DAMASCENO-SILVA, K. J. Estatística da Produção de feijão caupi. 2009. Disponível em: $<\mathrm{http}$ ://www.portaldoagronegocio.com.br/ conteudo.php?id=34241>. Acesso em: 22 jul. 2016.

DI TOMMASO, A. Germination behavior of common ragweed (Ambrosia artemisiifolia) populations across a range of salinities. Weed Science, Champaign, v. 52, n. 6, p. 1002-1009, 2004.

EMPRESA BRASILEIRA DE PESQUISA AGROPECUÁRIA - EMBRAPA. Cultivo do feijão-caupi - Sistemas de Produção. 2002. Disponível em: <http:// sistemasdeproducao.cnptia.embrapa.br/

FontesHTML/ Feijao/FeijaoCaupi>. Acesso em: 13 mar. 2016.

FERREIRA, D. F. Sisvar: a computer statistical analysis system. Ciência e Agrotecnologia, Lavras, v. 35, n. 6, p. 1039-1042, 2011.

FILGUEIRAS, G. C. et al. Aspectos socioeconômicos. In: ZILLI, J. E.; VILARINHO, A. A.; ALVES, J. M. A. (Eds.). A cultura do feijão-caupi na Amazônia brasileira. Boa Vista: Embrapa Roraima, 2009. v. 1, cap. 1, p. 23-58.

FRANCO, O. L. et al. Effects of $\mathrm{CaCl}_{2}$ on the growth and osmoregulator accumulation in $\mathrm{NaCl}$ stressed cowpea seedlings. Revista Brasileira de Fisiologia Vegetal, Campinas, v. 11, n. 3, p. 145-151, 1999.

HEYDECKER, W.; COOLBEAR, P. S. Seed treatmens for improved performance: survey and attempted prognosis. Seed Science \& Technology, Bassersdorf, v. 3, n. 3, p. 881-888, 1977.

LARCHER, W. Ecofisiologia Vegetal. 3. ed. São Carlos, SP: RiMa, 2006. 531 p.

MAGUIRE, J. D. Speed of germination-aid in selection and evaluation for seedling emergence and vigour. Crop Science, Madison, v. 2, n. 2, p. 176-177, 1962.

MORAES, G. A. F.; MENEZES, N. L.; PASQUALLI, L. L. Comportamento de sementes de feijão sob diferentes potenciais osmóticos. Ciência Rural, Santa Maria, v. 35, n. 4, p. 776-780, 2005. induzida por diferentes agentes osmóticos na germinação e vigor de sementes de feijão. Revista Brasileira de Sementes, Viçosa, v. 28, n. 1, p. 142-148, 2006.

MARCOS FILHO, J. Fisiologia de sementes de plantas cultivadas. 2. ed. Londrina, PR: ABRATES, 2015. $659 \mathrm{p}$.

PELEGRINI, L. L. et al. G. Efeito do estresse hídrico simulado com $\mathrm{NaCl}$, manitol e PEG (6000) na germinação de sementes de Erythrina falcata Benth. Ciência Florestal, Santa Maria, v. 23, n. 2, p. 511-519, 2013

PEREZ, S. C. J. G. A.; FANTI, S. C.; CASALI, C. A. Influência da luz na germinação de sementes de canafístula submetidas ao estresse hídrico. Bragantia, Campinas, v. 60, n. 3, p. 155-166, 2001.

SILVA JÚNIOR, E. B. et al. Nodulação e produção de feijão-caupi em resposta à inoculação com diferentes densidades rizobianas. Pesquisa Agropecuária Brasileira, Brasília, v. 49, n. 10, p. 804-812, 2014

SOUZA, M. P. et al. Estresse hídrico e salino no processo germinativo das sementes de Plantago ovata Forsk. (Plantaginaceae). Revista Árvore, Viçosa, v. 32, n. 1, p. 33-38, 2008.

TAIZ, L.; ZEIGER, E. Fisiologia Vegetal. 5. ed. Porto Alegre, RS: ARTMED, 2013.918 p.

VILLELA, F. A.; DONI FILHO, L.; SIQUEIRA, E. L. Tabela de potencial osmótico em função da concentração de polietileno glicol 6000 e da temperatura. Pesquisa Agropecuária Brasileira, Brasília, v. 26, n. 11-12, p. 1957-1968, 1991.

WENKERT, W.; LEMON, E. R.; SINCLAIR, T. R. Leaf elongation and turgor pressure in field; grown soybean. Agronomy Journal, Madison, v. 70, n. 5, p. 761-764, 1978.

YANG, T.; POOVAIAH, B. W. Hydrogen peroxide homeostasis: Activation of plant catalase by calcium/ calmodulin. Proceedings of National Academy of Sciences of the United States of America, Washington, v. 99, n. 6, p. 4097-4102, 2002.

YOON, Y. et al. Priming with salt solutions improves germination of pansy seed at high temperatures. HortScience, Alexandria, v. 32, n. 2, p. 248-250, 1997.

MACHADO NETO, N. B. et al. Deficiência hídrica 